\title{
Haploid transcriptome analysis reveals allelelic gene expression variants, co-expressed gene groups, and linkages between expression and copy number variation
}

\author{
Jukka-Pekka Verta ${ }^{1 *}$, Sebastien Caron ${ }^{1}$, Isabelle Giguère ${ }^{1}$, Brian Boyle ${ }^{1}$, Christian R Landry², John Mackay ${ }^{1}$ \\ From IUFRO Tree Biotechnology Conference 2011: From Genomes to Integration and Delivery \\ Arraial d Ajuda, Bahia, Brazil. 26 June - 2 July 2011
}

\section{Background}

Genetic variation can cause changes in gene expression (mRNA abundance) among individuals. This so-called heritable variation in gene expression is affected by genetic variants that are co-segregating with the gene locus (local/cis effects) and/or segregating independently from it (distant/trans effects). Genetic variation in gene expression can be measured to estimate the extant of variation in gene expression within a population, and to determine to what degree expression alleles of different genes are connected within regulatory networks. Furthermore, determining whether variation in the expression of a gene is linked to local or distant effects allows us to make inferences about how heritable variation may change depending on gene function, the number of interacting partners, genetic architecture and evolutionary history $[1,2]$.

Detecting heritable variation in gene expression can be a challenging task in diploid organisms, mainly because of tissue-specificity and dominance effects of allelic expression. For example, up to $70 \%$ of gene expression alleles in Drosophila may be masked by dominance [3]. We developed an experimental system to overcome these obstacles by utilizing the conifer seed's maternally derived haploid tissue, the megagametophyte. Analyzing a set of sibling megagametophytes allows us to first, measure separately the expression each of the two alleles in the maternal genome in the absence of dominance and second, identify genes whose expression levels are co-segregating. In addition, the megagametophyte allows

* Correspondence: jukka-pekka.verta.1@ulaval.ca

${ }^{1}$ Centre d'étude de la forêt, Université Laval, Québec QC, Canada

Full list of author information is available at the end of the article us to categorize the underlying genetic variants into local or distant with a simple co-segregation assay.

\section{Methods}

We set out to characterize segregating variation in gene expression in white spruce (Picea glauca [Moench] Voss). We analyzed the transcriptomes of germinating sibling megagametophytes from two controlled-crossed families (C9412516: male 2388 x female 77111 \& C9612856: male $80109 \times$ female 80112) with a custom microarray comprised of 32,000 spotted oligonucleotides, which represent over 25,000 unique white spruce genes. Each megagametophyte was split into two halves to provide technical replicates that were analyzed separately. A separate comparison of microarray results and RNA-Seq data has been carried out to validate the quality of the microarray.

The single-color microarray data was background-corrected and quantile-normalized with the $R$ package Limma [4]. We used the R package Mclust [5] to test for unimodal vs. bimodal expression distributions of each gene across sibling megagametophytes. Genes that exhibited at least two expression alleles, which segregated within the $95 \%$ IC of their expected proportions, were selected. The segregation had to be repeatable with a replicate sample set to be considered valid.

\section{Results and discussion}

Analysis of two families of sibling megagametophytes $(n=18)$ identified close to a thousand genes with segregating gene expression patterns in both of the two families. Approximately $10 \%$ of these genes were shared. Zero replicates are expected to have the same clustering 
pattern by chance alone (binomial $p \approx 3.810-6 \mid \mathrm{n}=18$ ). The number of variable genes is comparable to that found between 50 nearly isogenic Drosophila lines [6].

We have discovered a large number of genes with gene expression patterns segregating in a Mendelian way in white spruce. We are presently analyzing the relationships between gene function and paralog number with the variation in its expression in order to determine whether heritable variation in gene expression is associated with same genetic attributes in white spruce as what has been reported in model organisms. We have also begun investigating the contribution of local vs. distant effects on the expression alleles identified in the megagametophytes, and their nature, by studying the co-segregation of gene expression, SNPs and copy number variations $(\mathrm{CNVs})$. Preliminary comparative genomic hybridization data suggests a significant portion of genes which show segregating gene expression alleles also exhibit CNVs. In follow-up experiments, we will address the amount of dominance between the gene expression alleles by comparing gene expression in megagametophytes versus self-fertilized embryos.

\section{Acknowledgments}

The seed material was provided by J. Beaulieu (Canadian wood fibre centre).

\section{Author details}

${ }^{1}$ Centre d'étude de la forêt, Université Laval, Québec QC, Canada.

2Department of Biology, Université Laval, Québec QC, Canada.

Published: 13 September 2011

\section{References}

1. Landry CR, Lemos B, Rifkin SA, Dickinson WJ, Hartl DL: Genetic properties influencing the evolvability of gene expression. Science 2007, 317:118-121.

2. Kliebenstein D: A role for gene duplication and natural variation of gene expression in the evolution of metabolism. PLOS One 2008, 3:e1838.

3. Lemos B, Araripe LO, Fontanillas P, Hartl DL: Dominance and the evolutionary accumulation of cis-and trans-effects on gene expression. PNAS 2008, 105:14471-14476.

4. Smyth GK, Speed T: Normalization of cDNA microarray data. Methods 2003, 31:265-273.

5. Fraley C, Raftery AE: MCLUST version 3 for R: Normal mixture modeling and model-based clustering. University of Washington Tech Report 2009, 504.

6. Hsieh W, Passador-Gurgel G, Stone EA, Gibson G: Mixture modeling of transcript abundance classes in natural populations. Genome Biology 2007, 8:R98.

doi:10.1186/1753-6561-5-S7-047

Cite this article as: Verta et al: Haploid transcriptome analysis reveals allelelic gene expression variants, co-expressed gene groups, and

linkages between expression and copy number variation. $B M C$ Proceedings 2011 5(Suppl 7):047.

\section{Submit your next manuscript to BioMed Central and take full advantage of:}

- Convenient online submission

- Thorough peer review

- No space constraints or color figure charges

- Immediate publication on acceptance

- Inclusion in PubMed, CAS, Scopus and Google Scholar

- Research which is freely available for redistribution

Submit your manuscript at www.biomedcentral.com/submit
C Biomed Central 